Grosul V., Ivanova $\mathbf{T}$.

\title{
RESEARCH OF THEORETICAL BASIS OF BUSINESS MODEL QUALITY MANAGEMENT OF RESTAURANT BUSINESS ENTITY
}

Узагальнено теоретичні положення та розкрито сутність поняття «управління якістю». Ідентифіковано основні акценти щодо визначення сутності поняття «управління якістю». Виділено сутнісні ознаки управління якістю бізнес-моделі підприємства ресторанного господарства та уточнено його сутність. Досліджено тенденції розвитку конщепцї «управління якістю» та обгрунтовано необхідність застосування інноваційного підходу до побудови системи управління якістю бізнес-моделі підприємства ресторанного господарства.

Ключові слова: управління якістю, бізнес-модель підприємства, ресторанне господарство, вимоги споживачів, інноваційний підхід.

\section{Introduction}

Restaurant business is one of the promising sectors of the economy of Ukraine. Service market of restaurant business entities is growing dynamically and has mainly positive dynamics. Restaurant business entities independently determine rational options to balance the interests of all stakeholders, including consumers. At the same time, increasing competition in the industry and the need to ensure timely response entities to rapid changes in the environment highlight the problem of quality control.

The recent increased interest in issues of quality control is due to the fact that formation of sustainable competitive advantages is possible with the implementation of qualitative business model of restaurant business entity, the success of which, in turn, is determined by the degree of satisfaction of the interests of all stakeholders. This requires creation of evidence-based methods and mechanisms of business model quality management of restaurant business entity corresponding modern realities of internal and external environment. Researches aimed at solving problems in this area are certainly relevant.

\section{The object of research and its technological audit}

New technologies require original business models that allow restaurant business entities to convert technology innovation in commercial success. Research of foreign experience for implementation of new software and technological support for the organization of electronic restaurant is conducted in order to form an effective business model quality management system of Ukrainian restaurant business entities. It is found that an effective tool that minimizes waiters' errors and makes restaurant visiting easier and more comfortable for the client system is e-Menu. The success of this innovation is confirmed by the experience of the Israeli company «Concepric», which since mid-2000s implements e-Menu system in sushi bars, pubs and family restaurants (touch screen terminal is fixed on each table), a similar system in Japan is provided by the company Aska T3, Microsoft has developed a solution Microsoft Surface, which turns the whole table in the large touch screen. E-Menu system creates an opportunity to work in real time and allows to view tables, catalogs menu under the title and ingredients, track sales processes, open tables, form and send orders to the kitchen. Implementation of this innovation in activity of domestic restaurant business entities will significantly improve service and significantly accelerate the process of customer service.

\section{The aim and objectives of research}

The aim of research is theoretical framework for business model quality management of restaurant business entities.

To achieve this aim it is necessary:

1. Conduct a critical analysis of interpretations of the essence of «quality control» concept and identify its key focus.

2. Define basic essential features of «quality management» concept including features of restaurant business entities.

3. Summarize theoretical principles and improve the conceptual framework of the theory of quality management in terms of clarifying the essence of «business model quality management of restaurant business entity» concept.

4. Examine trends of «quality control» concept and justify the need to improve business model quality management of restaurant business entity through an innovative approach.

\section{Research of existing solutions of the problem}

Various aspects of quality management are the subject of active scientific research of significant number of domestic and foreign researchers. An important contribution to the development of theoretical and methodological principles of quality management is implemented by the scientists [1,2]. System and categorical researches of quality management system are highlighted in [3]. 
The problem of determining the socio-economic essence of «quality management» concept and its provision in a market is considered in the study [4]. Economic aspects of product certification and quality management systems according to international standards are highlighted in [5]. Theoretical aspects of relationship of quality management and management quality are studied in [6]. In [7] the basic criteria for evaluating the effectiveness of the management of the enterprise are defined.

Increased interest in the problems of enterprise quality management among scientists was the precondition for a modern approach to management - management of competitiveness. Leading experts on quality management proposed a number of structure diagrams of total quality management, which became the main basis for the formation of «System of quality standards ISO-9000».

However, the study of published works and practice of economic activity indicate insufficient coverage of critical issues related to the theoretical and methodological support of formation of business models of restaurant business entities, using modern methods of quality control of its individual elements and modern concepts of quality management in determining directions of upgrading the existing business models of restaurant business entities.

A significant amount of scientific works of domestic and foreign scientists are devoted to analysis of the business model of enterprises. Scientists are used different approaches for analysis of business models of the enterprises: component, functional, systematic, integrated, marketing, process and others.

The team of foreign scientists [8] for the development and analysis of the existing business model is offered approach $\ll 4 \mathrm{~W} »$ :

1) what (what decisions are made in the business model);

2) when (when they are made);

3) who (who are made them);

4) why (why they are made).

Scientists recommend to focus attention on two main types of risks: information risk and risk of motivation non-compliance.

An approach to the analysis of business models represented in [9] has a great interest. The scientist focuses on the need for a systematic approach to analyze the business model and offers to perform a detailed analysis of the main components of the business model (the function and purpose of business, value proposition, market, processor (chain values, key resources, catalyst, human resources), competition strategy, business network, economic model), which recommends to describe in terms of four key dimensions: static, control, dynamic and predictive.

To assess the effectiveness of the current business model of the enterprise, a number of scientists are used concept «Performance Management based on Balanced ScoreCard, BSC)» [10], which allows to combine the development strategy of operational activities and cost factors. The main feature of the balanced scorecard is that it allows to analyze the business model in the context of communications with business processes, and take into account the demands and requests of customers.

In order to establish the key emphasis, which should be the focus for formation of business model of the enterprise the following aggregated components are revealed [11]:

- Infrastructure, which represented by the main market opportunities, affiliate network, changes in value.
- Offer, which is identified by the products and value propositions).

- Customer, which allows to provide a qualitative assessment of relations with customers.

- Finance, which are the costs and revenues of the enterprise.

The model «EP $\mathrm{P}^{2} \mathrm{M}$ ( (Effective Progress and Performance Measurement - evaluation of the effectiveness and growth) [12] has a great interest. It is an effective tool for analyzing business models. The key of this model is evaluating the effectiveness of enterprise business model in four directions:

1) in external environment - customer support and meet the demand;

2) in internal environment - improvement of efficiency and productivity;

3) from top to bottom in the organizational hierarchy expansion and adaptation of overall enterprise strategy on all the lower levels of the organizational structure, stimulation of changes;

4) from bottom to top in the organizational hierarchy the growing influence of shareholders and expand freedom of action of workers.

However, along with a significant interest in the research of outlined issues by scientists and specialists there is no generally accepted view on key aspects of the quality of the business model of restaurant business entity, available methods and techniques of quality management aren't adapted to industry specifics of restaurant business entities, which necessitates further developments in this area.

\section{Methods of research}

The following methods are used to achieve the objectives: analysis and synthesis, induction and deduction, dialectic, abstract logical methods, comparative comparison, graphic-analytical methods.

\section{Research results}

The study of economic literature $[2-5,7,13-16]$ allows to reveal that quality management covers the part of management functions, aimed at achieving the quality objectives of a certain area. Quality objectives involve the creation of the enterprise environment in which it is possible to control and regulate the quality, ensure compliance with the established requirements and the flexibility to change the established requirements.

Quality management is essential element of enterprise management, a set of interrelated and interacting elements that allow to establish policies and objectives for quality and to achieve them. Quality management in international standards is defined as the coordinated activity that consists in directing and controlling the activities on quality [17].

The approach proposed in [13] has a great interest. It states that «quality management» - not a one-time event, and constant renewal movement. This should be the aim and method of management of the enterprise. At this level, it is understood that the quality management improves its competitiveness and contribute more and more satisfaction of needs and expectations.

Quite reasonable is opinion of a leading specialist in the field of quality management described in [5]. This 
paper states that «...the basic requirements of quality standards contain in the products (work, services), as well as consumer demand. Therefore, quality management ensures confidence in the implementation of these requirements, providing control as a process, as well as results of quality activities». This lexical interpretation of «quality management» category allows to establish that the activities of the quality management is emerged during the formation of labor activity. Obviously, the quality and aims of management were different, completely responsible constant change of values and tastes of the modern consumer.

«Economic aspects of product certification and quality management systems according to international standards» [1] defines the theoretical bases and trends of quality management. This paper summarizes the main reasons for introduction and certification of quality management systems, analyzes approaches to classification of quality costs; makes recommendations on implementation of state regulation and certification of quality management systems.

Ukrainian Quality Association defines the essence of the term «quality management» as the direction of the functions of general management, determining policy on quality, purpose and responsibility and carries them through such means as quality planning, quality control, quality assurance and quality improvement in the quality system [6].

The paper of Ukrainian scientist [18] focuses on the fact that quality management is the process of managing all stages of the product life cycle, and the relationship of all enterprise units to create a quality product to all industries and types of submission. This view coincides with the scientific approach to the author's understanding of the essence and the need to identify and formation of an effective quality management system in enterprises of different economic sectors. The modern world economy is a competitor fighting for consumer. Consumer is most satisfied when the quality of service (products) is fully consistent with its values.

Based on a critical analysis of scientific sources on the definition of quality management, lack of established conventional approach to defining is determined and the key points are identified (Table 1).

Table 1

The key points in determining the essence of «quality control» category in modern economic literature

\begin{tabular}{|l|l|}
\hline \multicolumn{1}{|c|}{ Key point } & \multicolumn{1}{c|}{ Essence } \\
\hline $\begin{array}{l}\text { 1. Consideration of } \\
\text { quality management } \\
\text { as a management tool }\end{array}$ & $\begin{array}{l}\text { The essence of the category is revealed through the } \\
\text { determination of management processes improvement, } \\
\text { i. e. the movement of business processes structure } \\
\text { and output management results }\end{array}$ \\
\hline $\begin{array}{l}\text { 2. Quality manage- } \\
\text { ment - the process } \\
\text { of managing all sta- } \\
\text { ges of the life cycle } \\
\text { of services (products) }\end{array}$ & $\begin{array}{l}\text { The essence of the category is revealed through the } \\
\text { control organization over the process of creation } \\
\text { development starts with defining the requirements and } \\
\text { needs of consumers and ends when the prototype is } \\
\text { ready to mass production }\end{array}$ \\
\hline $\begin{array}{l}\text { 3. Quality manage- } \\
\text { ment is evaluation } \\
\text { system of adminis- } \\
\text { trative work }\end{array}$ & $\begin{array}{l}\text { Duality management is an integral function of ma- } \\
\text { nagement activities and provides an implementation } \\
\text { of complex works on research and self-analysis as } \\
\text { a part of the management process }\end{array}$ \\
\hline
\end{tabular}

Note: developed by the authors based on the summary of $[5,8,9,13]$.

These moments indicate the complexity of «quality control» concept and the ambiguity of its contents. However, despite the invariance of existing approaches, quality management process is based on the principles of trust management system and quality management to ensure the integrity and balance the interests of enterprise and consumers.

Essential features of «quality management» category for restaurant business entities are identified taking into account the specifics of restaurant business entity (Table 2).

Table 2

The essential features of «quality management» category that take into account the specifics of restaurant business industry

\begin{tabular}{|l|l|}
\hline \multicolumn{1}{|c|}{$\begin{array}{c}\text { Essential of the } \\
\text { feature }\end{array}$} & \multicolumn{1}{|c|}{ Characteristic } \\
\hline $\begin{array}{l}\text { The aim of manage- } \\
\text { ment }\end{array}$ & $\begin{array}{l}\text { Support of level and quality state in accordance with } \\
\text { the values of consumers }\end{array}$ \\
\hline Objective & $\begin{array}{l}\text { Eliminating differences between the level of customer } \\
\text { satisfaction and producer proposition }\end{array}$ \\
\hline Management object & $\begin{array}{l}\text { Quality of provided service; } \\
\text { Production of culinary products; } \\
\text { Sales of culinary products; } \\
\text { Organization of product consumption }\end{array}$ \\
\hline Management subject & $\begin{array}{l}\text { Structural business units of all levels of management } \\
\text { hierarchy and the person providing the level of quality } \\
\text { of production (technology) }\end{array}$ \\
\hline $\begin{array}{l}\text { Methods and means } \\
\text { of management }\end{array}$ & $\begin{array}{l}\text { The way in which management effects on support of } \\
\text { high-level state and quality of the service }\end{array}$ \\
\hline Functional orientation & Subordination by strategic goals of quality management \\
\hline Time lag & $\begin{array}{l}\text { Short term of implementation cycle (rendering of } \\
\text { service) }\end{array}$ \\
\hline Value priorities & Keeping customer loyalty (clients) \\
\hline
\end{tabular}

Note: author's development.

Based on the study of invariant interpretations of the essence of «quality control» concept, author's vision of the concept of «business model quality management of restaurant business entity» is proposed. It is coordinated activity of controlling the value propositions (range, food sales concept, service level), key partners, consumer segments, key resources, cost structure, relationships with customers, revenue streams. Ensuring the required level of quality of the business model of restaurant business entity requires not only advanced production technology, necessary material resources, qualified staff, and the rational organization of work, effective business management involving quality management system.

6.1. Research of trends of «quality control» concept and general management. Development of quality management system is not just a program, it's a constant process of achieving a superior level of quality, which in itself is the driving purpose and means a fixed meet of agreed customer requirements and unleashing the potential of all employees.

Practical experience of successful enterprises in various sectors of the economy of developed countries shows that in the context of globalization, the expansion of industrial, economic, scientific, technical, organizational relationships, increasingly growing requirements for the formation of the contemporary realities of the quality management system of goods and services. The problem of improving the quality is not only the top problem, but it is a national priority in ensuring the competitiveness of products and services and meet social demands of the population. 
Quality management systems are improved over time. Studies have shown that the object of management at the initial stage was the quality of material products and services had a secondary role. However, transition to a market economy shifted focus for the modern concept of quality management towards service quality as the main factor of competitiveness (Table 3 ).

Table 3

The generalized trend analysis of "quality control" concept and general management

\begin{tabular}{|c|c|}
\hline Period & Key points in quality management \\
\hline $\begin{array}{l}\text { 1900-1920. } \\
\text { Taylor system }\end{array}$ & $\begin{array}{l}\text { Phase of individual quality control and rejection (1870s - } \\
\text { early 20th century). Individual quality control of each } \\
\text { worker. Appearance of the Ford-Taylor system. Thus, } \\
\text { the responsibility for making all products was assigned } \\
\text { to one worker or a small group. Product quality was } \\
\text { ensured by means of total control quality parameters of } \\
\text { products and the results of their labor by the worker. In } \\
\text { this case, workers had to perform the work according } \\
\text { to a certain model (pattern, drawings, etc.) [6] }\end{array}$ \\
\hline $\begin{array}{l}1920-1950 . \\
\text { Classical qual- } \\
\text { ity management } \\
\text { school }\end{array}$ & $\begin{array}{l}\text { Phase of quality control (1920s). Introduction of statisti- } \\
\text { cal control methods and quality control, W. Shewhart } \\
\text { control cards. Its appearance was due to the deepening } \\
\text { of inner division of labor and the expansion of industrial } \\
\text { production. The characteristic feature of this stage was } \\
\text { the distribution of roles and responsibilities for quality } \\
\text { not only between individual workers, but the supervisor. } \\
\text { Shop control was based on the principles of scientific } \\
\text { management, the author of which was a leading American } \\
\text { scientist in the field of management F. Taylor [1] }\end{array}$ \\
\hline $\begin{array}{l}\text { 1950-1980. } \\
\text { System manage- } \\
\text { ment }\end{array}$ & $\begin{array}{l}\text { Phase of quality management (1950s). The emergence } \\
\text { of the Japanese system of «Total Quality Control» (TQC), } \\
\text { the concept of "Zero defects». Formation of quality } \\
\text { management methodologies by E. Deming and J. Juran. } \\
\text { Development of mass production, increase of the number } \\
\text { of industrial enterprises, increase of production volumes } \\
\text { before World War II caused the disassociation of techni- } \\
\text { cal contral, until its execution in an independent activity, } \\
\text { from industrial operations. So, new approaches to tech- } \\
\text { nical control were promoted to ensuring the quality of } \\
\text { production processes. Conceptual foundations of this } \\
\text { approach are mathematical statistics and probability } \\
\text { theory. Characteristic features of this phase are replace } \\
\text { of the continuous monitoring by selective monitoring and } \\
\text { use of W. Shewhart control cards [18] }\end{array}$ \\
\hline $\begin{array}{l}\text { 1980-present. } \\
\text { Target, branch } \\
\text { management, in- } \\
\text { tegrated systems }\end{array}$ & $\begin{array}{l}\text { Total (overall) quality management (TQM) (1980s). Deve- } \\
\text { lopment of a series of international standards IS0 } 9000 \\
\text { had a significant impact on the management and quality } \\
\text { assurance. Formation of quality services at enterprises } \\
\text { allows to eliminate double subordination of workers } \\
\text { who are responsible not only for production, but also } \\
\text { should assess its quality. The fifth stage is movement } \\
\text { from normal quality control to quality management. } \\
\text { Achievement of this level of product quality was the } \\
\text { target of integrated quality management. This step was } \\
\text { done with development of ISD 9000. According to this } \\
\text { methodology, to create highly efficient and effective } \\
\text { enterprise quality systems that comply with the provi- } \\
\text { sions of ISO 9000 is a guarantee that the requirements } \\
\text { of consumers are really satisfied [14]. As well as the } \\
\text { improvement of international standards, the growing } \\
\text { influence of consumers on business processes }\end{array}$ \\
\hline
\end{tabular}

Note: developed by the author based on a summary of $[1,6,14,18]$.

It is important to emphasize that the current stage of development of quality management concept is characterized by the integration of new elements of the management system, at the same time in the overall management there is a tendency of differentiation into separate areas: finance, personnel, innovation, marketing, investment and theoretical terms of general management are formed as target-oriented management.

Profit maximization of restaurant business entities largely depends on the needs and demands of consumers, so all existing business processes should be focused on providing high quality products and services focused on full implementation of the overall quality policy. Quality improvement of business model of restaurant business entity in high competition is only possible through an innovative approach. The specifics of the restaurant business, as a service industry, provides in innovation not only improve the quality of life (meet the need for quality (environmental aspect), beautiful and tasty cooked food (aesthetic pleasure)), but corrected relationships with customers, competent marketing policy and PR strategy, and accounting of necessity for innovation commercialization (patents, registration of corporate trademarks). Overall, the innovative project of this kind is a complex system of interrelated and interdependent measures (resources, timing and executing) designed to achieve specific goals (tasks) in priority areas of science and technology.

Developing a quality management system of business model of restaurant business entities, it should take into account that the process of production and commercial activities of restaurant business entity is the logistics cycle, defined by period of time since the organization of the production process until the moment when customer paying money for products and services. Considering this, business model quality management of restaurant business entity should be carried out at all stages of interaction of resources in accordance with the model:

$$
M \rightarrow P \rightarrow \text { Production } \rightarrow P^{\prime} \rightarrow M^{\prime},
$$

where $M, P$ - money and products invested in production; $P^{\prime} \rightarrow M^{\prime}$ - product obtained as a result of production and money obtained as a result of its sale.

This approach allows to provide a systematic and comprehensive business model quality management of restaurant business entity depending on the cooperation with key partners (suppliers of raw materials, intermediate products and other products); cook professionalism and competence of other categories of restaurant business workers, depends on the demand quality (products and services) that contributes to formation of customer value and leads to the growth of revenues and profits.

\section{SWOT analysis of research results}

Strength of this research is definition of the key aspects of business model quality management of restaurant business entity taking into account a specific of the restaurant business as service industries and justification of the importance of an innovative approach in the development of the strategic vectors for qualitative renewal of existing business models of the restaurant business in stages: production, distribution, exchange and consumption.

Weakness is the fact that innovative renewal of existing business models of restaurant business entities needs additional funding. A favorable investment climate at the national level must be created for additional financial investments in the restaurant business.

Opportunities for further researches are adopting the experience of foreign countries to effectively implemen- 
tation of technological, organizational and other innovations in the formation of high-quality business model of restaurant business entity.

Threats to the research results are the fact that it is impossible to create a qualitative business model of restaurant business entity in conditions of high uncertainty and constant variability of the environment. Change of environmental conditions, requirements and demands of consumers necessitates adjustments of identified key points in business model quality management of restaurant business entity.

\section{Conclusions}

Research results and practical experience indicate that the sustainable development of restaurant business entities in the long term in the contemporary economy depends on its ability to adapt to constantly changing market environment in a dynamic competitive environment. The basis for ensuring the competitiveness of the modern restaurant business entity is its business model, which is a set of interrelated strategic decisions that form the way of industrial and commercial activity, which determines creation and appropriation of value of products (services) in the total network of value creation, and provides a dynamic balance of all subsystems of restaurant business entity.

The results of theoretical research identify essential features and major dominant business model quality management of restaurant business entities. For this:

1. Critical analysis of invariant interpretations of the essence of «quality control» concept is conducted and its key points are identified (as management function, management process and a system of evaluation of management activities).

2. Based on a synthesis of existing approaches to the interpretation of the essence of «quality management» concept including industry features of restaurant business entity, its basic essential features are defined (aim of management, objectives, object, subject, methods and means of management, functional orientation, time lag, value priorities).

3. Conceptual framework of quality management theory is improved in terms of clarifying the essence of «quality management business model of enterprise restaurant management» concept, which it is proposed to define as a coordinated activity that is controlling the value propositions (range, food sales concept, service level), key partners, consumer segments, key resources, cost structure, relationships with customers, revenue streams.

4. Examination of trends of «quality management» concept and general management allows to determine that quality improvement of enterprise business model is based on an innovative approach to management at all stages of production, distribution, exchange and consumption.

The practical significance of these results is determination of the basic elements of a business model quality management system of restaurant business entity: value propositions, key partners, consumer segments, key resources, cost structure, relationships with customers, revenue streams.

\section{References}

1. Kyslytsyn, V. O. Rozvytok systemy upravlinnia yakistiu na pidpryiemstvi [Text]: Monograph / V. O. Kyslytsyn; Institute of Industrial Economics of NAS of Ukraine. - Donetsk, 2009. - 188 p.

2. Simenko, I. V. Yakist system upravlinnia pidpryiemstvamy: metodolohiia, orhanizatsiia, praktyka [Text]: Monograph / I. V. Simenko; by ed. O. O. Shubin. - Donetsk: Donetsk National University of
Economics and Trade named after Mykhailo Tugan-Baranovsky, 2009. - 394 p.

3. Potapchik, O. A. System-categorical research the quality in the management system [Text] / O. A. Potapchik // Odesa National University Herald. Economy. - 2013. - Vol. 2/1, № 18. - P. 9-104.

4. Samoilenko, I. O. Sotsialno-ekonomichna sutnist poniattia «yakist menedzhmentu» ta yii zabezpechennia $\mathrm{v}$ umovakh rynku [Text] / I. O. Samoilenko, K. O. Ostapenko // Komunalne hospodarstvo mist. - 2014. - Vol. 113. - P. 245-252.

5. Bibik, Yu. V. Ekonomichni aspekty sertyfikatsii produktsii ta system upravlinnia yakistiu za mizhnarodnymy standartamy [Text]: PhD thesis: 08.06.01 / Yu. V. Bibik. - Kharkiv, 2003. - 227 p.

6. Kalyta, T. V. Vzaiemozviazok upravlinnia yakosti i yakosti upravlinnia [Text] / T. V. Kalyta // Zbirnyk tez dopovidei IX Mizhnarodnoi naukovoi konferentsii «Problemy ekonomiky transportu», 22-23 kvitnia 2010 r. - Dnipropetrovsk: DNUZT, 2010. - P. 58

7. Krainev, V. A. K voprosu ob effektivnosti sistemy menedzhmenta [Text] / V. A. Krainev // Metody menedzhmenta kachestva. - 2004. - № 9. - P. 21-26.

8. Dada, O. (Lola). Entrepreneurial tendencies in franchising: evidence from the UK [Text] / O. (Lola) Dada, A. Watson, D. Kirby // Journal of Small Business and Enterprise Development. - 2015. - Vol. 22, № 1. - P. 82-98. doi:10.1108 jsbed-11-2011-0021

9. Strekalova, N. Business model concept: methodology of system analysis [Text] / N. Strekalova // Izvestia: Herzen University Journal of Humanities \& Science. - 2009. - № 92. - P. 95-105.

10. Dorf, R. C. The Balanced Scorecard: Translating Strategy Into Action [Book Reviews] [Text] / R. C. Dorf, M. Raitanen // IEEE Transactions on Engineering Management. - 1997. Vol. 44, № 3. - P. 330-331, doi:10.1109/tem.1997.618174

11. Osterwalder, A. Business Model Generation: A Handbook for Visionaries, Game Changers, and Challengers [Text] / A. Osterwalder, Y. Pigneur. - John Wiley \& Sons, Inc., 2010. - 288 p.

12. Freese, W. You Cannot Manage, What You Cannot Measure [Text] W. Freese // Praxishandbuch Corporate Magazines. - Springer Nature, 2012. - P. 202-217. doi:10.1007/978-3-8349-3702-5_18

13. Okrepilov, V. V. Upravlenie kachestvom [Text]: Textboo $\bar{k}$ V. V. Okrepilov. - Ed. 2. - Moscow: Ekonomika, 2008. - 639 p.

14. Karpenko, E. M. Menedzhment kachestva [Text]: Textbook / E. M. Karpenko, S. Yu. Komkov. - Minsk: IVTs Minfina, 2007. - 208 p.

15. Mazur, I. I. Upravlenie kachestvom [Text]: Textbook / I. I. Mazur, V. D. Shapiro; by ed. I. I. Mazur. - Moscow: Vysshaia shkola, 2003. - 334 p.

16. Shapoval, M. I. Menedzhment yakosti [Text]: Textbook M. I. Shapoval. - Ed. 3. - Kyiv: Znannia, KOO, 2007. - 471 p.

17. Bastrykin, D. V. Upravlenie kachestvom na promyshlennom predpriiatii [Text] / D. V. Bastrykin, A. I. Evseichev, E. V. Nizhegorodov et al.; by ed. B. I. Gerasimov. - Moscow: Mashinostroenie, 2006. - 204 p.

18. Kontseptsiia [Electronic resource] // Gufo.me. - Available at: \www|URL: http://mirslovarei.com/content_bes/koncepcija-29626.html. - 03.01.2017.

\section{ИССЛЕДОВАНИЕ ТЕОРЕТИЧЕСКИХ ОСНОВ УПРАВЛЕНИЯ КАЧЕСТВОМ БИЗНЕС-МОДЕЛИ ЛРЕДПРИЯТИЯ РЕСТОРАННОГО Х0ЗЯЙСТВА}

Обобщены теоретические положения и раскрыта сущность понятия «управление качеством». Идентифицированы основные акценты относительно определения сущности понятия «управление качеством». Выделены сущностные характеристики управления качеством бизнес-модели предприятия ресторанного хозяйства и уточнена его сущность. Исследованы тенденции развития концепции «управление качеством» и обоснована необходимость построения системы управления качеством бизнес-модели предприятия ресторанного хозяйства на основе инновационного подхода.

илючевые слова: управление качеством, бизнес-модель предприятия, ресторанное хозяйство, требования потребителей, инновационный подход.

Grosul Victoria, Doctor of Economic Sciences, Professor, Department of Economics and Management, Kharkiv State University of Food Technology and Trade, Ukraine, e-mail: vikgros@mail.ru, ORCID: http://orcid.org/0000-0002-2019-3853

Ivanova Tatyana, Senior Lecturer, Department of Economics and Management, Kharkiv State University of Food Technology and Trade, Ukraine, e-mail: ivanova77@meta.ua, ORCID: http://orcid.org/ 0000-0003-1260-7654 